\title{
Fabrication of Herbicide Biosensors Based on the Inhibition of Enzyme Activity That Catalyzes the Scavenging of Hydrogen Peroxide in a Thylakoid Membrane
}

\author{
Jianping LI, *† Xiaoping WeI,* and Tuzhi PENG** \\ *Department of Material and Chemistry Engineering, Guilin University of Technology, Guilin 541004, China \\ **Department of Chemistry, Zhejiang University, Hangzhou 310028, China
}

\begin{abstract}
A novel herbicide biosensor with a thylakoid modified membrane electrode is presented. Thylakoid, isolated from spinach leaves, was entrapped in a membrane of poly (vinylalcohol) with the styrylpyridinium group (PVA-SbQ). The thylakoid membrane was fixed on the surface of a platinum electrode. It was found that the enzymes in thylakoid kept their activity for several months in the membrane. The oxidative current of hydrogen peroxide in a Tris- $\mathrm{HCl}$ buffer solution ( $\mathrm{pH}$ 7.4) was detected at the modified electrode by a differential pulse voltammetric method. In the presence of herbicides, the oxidation current from the hydrogen peroxide decreased due to an inhibitor effect on the enzymes in thylakoid compared with that in the absence of the herbicides. The changes in the oxidation current at the electrode were proportional to the herbicide concentrations. The sensor could be used to detect herbicides in concentration ranges of $3 \times$ $10^{-9}-1.5 \times 10^{-7} \mathrm{M}$ for paraquat, $1 \times 10^{-8}-3 \times 10^{-7} \mathrm{M}$ for diuron, $4 \times 10^{-8}-3 \times 10^{-6} \mathrm{M}$ for prometryn, $5 \times 10^{-8}-5 \times 10^{-6}$ $\mathrm{M}$ for atrazine and $1 \times 10^{-7}-5 \times 10^{-6} \mathrm{M}$ for ametryn, respectively. The enzyme activity on scavenging hydrogen peroxide in the modified PVA-SbQ membrane was examined.
\end{abstract}

(Received January 14, 2005; Accepted April 25, 2005)

\section{Introduction}

With the extensive use of herbicides, it is almost impossible to avoid daily exposure to a number of herbicides in both food and water. Environmental pollutions have been produced due to their high toxicity, even at very low concentration. For example, accidental and suicidal poisonings caused by intensive use of herbicide were often encountered. This has led to an increase in public concern about possible health risks due to chronic toxicity. ${ }^{1}$ Community of European Union and some countries have set a maximum admissible concentration of 0.1 $\mu \mathrm{g} / \mathrm{L}$ for any individual herbicide and $0.5 \mu \mathrm{g} / \mathrm{L}$ for the total in water for human consumption. Thus, much attention has been devoted to studies on analytical methods that are simple, rapid and reliable for their determinations in samples. Various techniques have been described, such as chromatography and spectrophotometry. ${ }^{2-5}$ Currently, chromatography (either gas or liquid chromatography) is used in most methods for the determination of herbicide in water. However, some of these methods are time-consuming, particularly those are not suitable for on-site analysis.

So far, many interesting electrochemical methods have been developed for trace amount analysis. Electrochemical detection has many advantages, such as low cost, micronization and easy operation. It is suitable for on-sit analysis, especially for rapid determination. Several kinds of electrochemical sensors for the determination of herbicide have been reported. ${ }^{6-17}$ Most of them were based on enzyme-linking immunoassay, ${ }^{7-10}$ in which

† To whom correspondence should be addressed.

E-mail: likianping@263.net herbicides were detected by competitive reactions with labeled antibodies. Although the immunoassay permits one to detect herbicide with high sensitivity, the procedure is complicated, and it is difficult to monitor mixed herbicides because of the specificity of antibodies. In order to detect pollution in the environment and farm products, a few sensors based on the photosynthesis-inhibiting of herbicide on photosystem II (PSII) of chloroplast thylakoid have been developed. ${ }^{11-17}$ These sensors are suitable to detect all possible herbicides that inhibit photosystem II due to the receptor properties of the thylakoid membrane. However, the devices and procedures are complicated, since highly intense irradiation is needed. There have been few potentiometric sensors (ion selective electrodes) reported. ${ }^{18}$ However, only herbicides that charged positively could be determined by this kind of sensor.

In this paper, a new approach for determining total herbicides is presented. A herbicide biosensor based on the activityinhibiting of enzymes in thylakoid on scavenging hydrogen peroxide was constructed. It is difficult to effectively immobilize thylakoid, because of the short lifetime of enzymes in isolated thylakoid. ${ }^{19-26}$ Poly(vinylalcohol) (PVA) is a polymer that is frequently used as a matrix for the immobilization of various enzymes and cells. ${ }^{27}$ The polymer uses the addition of styrylpyridinum groups attached to the poly(vinylalcohol) to cross-link the polymer chains under mild conditions without damaging the biological material to be entrapped. This physical method has been proved to be effective in the fabrication of biosensors. In experiments, we conveniently immobilized thylakoid in a PVA-SbQ membrane to prepare a long-lifetime biosensor. The activity of enzymes in the membrane was used to detect trace-level amounts of herbicides indirectly. 
The mechanism that herbicides inhibit the Hill reaction of photosynthesis by hydrogen-peroxide bonding to electrontransport enzymes in chloroplast is quite different from photosynthesis-inhibition. ${ }^{11-17}$ The enzymes involved in the degradation of hydrogen peroxide are mainly ascorbate peroxidase (AsA-POD), dehydroascorbate reductase (DHAR) and glutathione reductase (GR). ${ }^{28}$ In plants, hydrogen peroxide, which is produced as the result of the Mehler reaction and the disproportionation of $\mathrm{O}_{2}^{-}$by superoxide dismutase (SOD), is removed by a series of reactions. In the first step, hydrogen peroxide is catalyzed by AsA-POD, which is effectively reduced to water. The primary oxidation product is monodehydroascorbate (MDA). MDA is reduced to AsA either by MDA reductase at the expense of NADH or NADPH, or by non-enzymatically disproportionation to dehydroascorbate (DHA) and AsA. It has been proved that the disproportionation reaction of MDA is dominant in thylakoid, because the MDA reductase does not participate in the reductive reaction. DHA is reduced to AsA by glutathione (GSH) with DHAR. Glutathione (GSSG) is reduced to GSH by GR using NADPH as an electron donor. NADPH is supplied by the photosynthetic electrontransport chain. Hydrogen peroxide is scavenged by multienzymes that participate in the cycle shown in Fig. 1. The scavenging is inhibited when the AsA-POD and probably GR are combined with herbicides.

\section{Experimental}

\section{Apparatus}

Voltammetric determinations were performed on a BAS100B/W electrochemical analyzer (Bioanalytical Systems, USA) with a platinum disc electrode (inner diameter of $2 \mathrm{~mm}$ ), an $\mathrm{Ag} / \mathrm{AgCl}$ reference electrode and a platinum counter electrode. The activity of thylakoid and the thylakoid membrane were determined at a Shimadzu spectrophotometer and enzyme-linked immune analyzer, respectively. Photographs were taken by means of a Hitachi SEM-570 scanning electron microscope (SEM). A Hitachi high-speed and frozen centrifuge was used for separation.

\section{Reagents}

The herbicides of atrazine, ametryn, diuron, paraquat and prometryn were purchased from Sigma or Aldrech respectively. The concentration of stock solutions for all herbicides was 0.01 $\mathrm{M}$ in 2\% alcohol solution. The working solutions were obtained by diluting stock solutions with $2 \%$ alcohol solution. PVASbQ, No. 912-980A (degree of polymerization, 3500; degree of saponification, 88\%; SbQ content, $1.34 \mathrm{~mol} \%$; solid content, 10.04 wt\%; pH 5.7) was a gift from Toyo Gosei Kogyo Co. Ltd., Japan. 2,6-dichlorophenylindophenol (DPIP), purchased from Sigma, was prepared in an aqueous solution $(0.3 \mathrm{mM})$. A hydrogen peroxide solution $(0.1 \mathrm{M})$ was prepared by diluting $100 \mu \mathrm{l}$ of $30 \%$ hydrogen peroxide in $10 \mathrm{ml}$ of double-distilled water and stored at $4^{\circ} \mathrm{C}$. All other chemicals used were of analytical reagent grade.

Several buffer solutions were prepared for the thylakoid membrane: buffer R1: $0.33 \mathrm{M}$ sorbitol, $50 \mathrm{mM}$ EDTA, $5 \mathrm{mM}$ sulfhydrylacetic acid, $0.1 \%$ bovine serum albumin (BSA) and 10 mM Tris- $\mathrm{NaOH}$ ( $\mathrm{pH}$ 8.0); buffer R2: 10\% saccharose, 50 mM EDTA, $5 \mathrm{mM}$ sulfhydrylacetic acid, $0.1 \%$ BSA and $10 \mathrm{mM}$ Tris- $\mathrm{NaOH}$ ( $\mathrm{pH}$ 8.0); buffer $\mathrm{R} 3$ : $75 \%$ saccharose, $50 \mathrm{mM}$ EDTA, $5 \mathrm{mM}$ sulfhydrylacetic acid, $0.1 \%$ BSA and $10 \mathrm{mM}$ Tris-NaOH ( $\mathrm{pH}$ 8.0); buffer $\mathrm{R} 4$ (suspending buffer): $0.3 \mathrm{M}$ mannitol, $2 \mathrm{mM}$ EDTA, $1 \%$ BSA and $2 \mathrm{mM}$ 4-

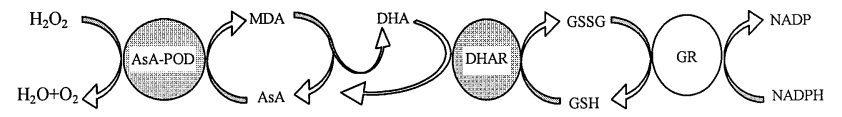

Fig. 1 Cycle of the AsA-POD/GR system on scavenging hydrogen peroxide.

morpholinepropanesulfonic acid (pH 7.9).

\section{Preparation of thylakoid}

Thylakoid was isolated from $100 \mathrm{~g}$ of deveined spinach leaves. ${ }^{29}$ Spinach leaves were washed with distilled water and then homogenized using an organic-tissue triturator in buffer R1 at $0^{\circ} \mathrm{C}$. The homogenate was separated centrifugally at $170 \mathrm{~g}$ for $1 \mathrm{~min}$ to remove any granules. The filtrate was centrifuged again at $1500 \mathrm{~g}$ for $15 \mathrm{~min}$. The pellets were moved in a hypotonic solution of buffer R2 in order to obtain free thylakoid fragments from broken chloroplast. Then, buffer R3 was added until the saccharose concentration of the solution was about 55 $56 \%$. The thylakoid was collected as pellets at $4000 \mathrm{~g}$ for $1 \mathrm{~min}$, and resuspended in buffer R4. The integrity of thylakoid was examined by a phase-difference microscope (Olympus BH2) in the suspending solution. Thylakoid in solution was quantified by measuring the chlorophyll (Chl) concentration according to the spectrophotometric procedure of Arnon. ${ }^{30}$ The thylakoid solution was diluted to a Chl concentration of $2 \mathrm{mg} / \mathrm{ml}$ with buffer R4. Aliquots were immediately stored at $-20^{\circ} \mathrm{C}$ before using.

Immobilization and quantification of thylakoid in the membrane A solution of PVA-SbQ was prepared by diluting the PVASbQ reagent with the buffer R4 (1:4, v/v). An aliquot of thylakoid solution $(1.0 \mathrm{ml})$ was mixed with $24 \mathrm{ml}$ of PVA-SbQ solution, and the gel was made homogeneously by agitation for 5 min at room temperature in the dark. The mixture was spread directly onto a plate of glass with an area of $300 \mathrm{~cm}^{2}$ in order to obtain a membrane. The membrane was cross-linked by exposing under UV radiation (235 and $365 \mathrm{~nm}$ ) for $5 \mathrm{~min}$, and dried for $24 \mathrm{~h}$ at $4^{\circ} \mathrm{C}$ in the dark. The resulting membrane was stored in the dark at $-20^{\circ} \mathrm{C}$.

The Chl concentration in the PVA-SbQ membrane was measured to quantify thylakoid. ${ }^{30}$ A testing membrane was obtained by injecting a $0.25 \mathrm{ml}$ mixture of the PVA-SbQ and thylakoid solution into a cell of 96-well microtitre plate. Then, $20 \mu \mathrm{l}$ of double-distilled water and $100 \mu \mathrm{l}$ of a $0.1 \mathrm{M}$ DPIP solution were poured into the cell, the sample was illuminated under UV light. The absorption at $630 \mathrm{~nm}$ was spectrophotometrically measured.

\section{Sensor fabrication and electrochemical determination}

A disk of thylakoid/PVA-SbQ membrane (diameter $5 \mathrm{~mm}$ ) was cut from the big membrane. It was sandwiched between two pieces of nylon mesh (diameter $1 \mathrm{~cm}$ ), and fixed carefully on the top of a platinum electrode with a rubber O-ring. The sensor was immerged in a Tris- $\mathrm{HCl}(\mathrm{pH} \mathrm{7.4)}$ buffer for $10 \mathrm{~min}$ before using.

Electrochemical determinations were carried out in obscuration to avoid strong light. A $50 \mathrm{mM}$ Tris- $\mathrm{HCl}$ buffer solution at $\mathrm{pH} 7.4$ with $1 \mathrm{mM} \mathrm{NaCl}, 5 \mathrm{mM} \mathrm{MgCl} 2$ and $8 \mathrm{mM}$ hydrogen peroxide (unless indicated elsewhere) was added into a 10-mL glass cell. $\mathrm{Mg}^{2+}$ was added to activate thylakoid-bound enzymes. The temperature was kept at $25^{\circ} \mathrm{C}$ by a thermostatic bath. The working electrode of the biosensor, $\mathrm{Ag} / \mathrm{AgCl}$ 


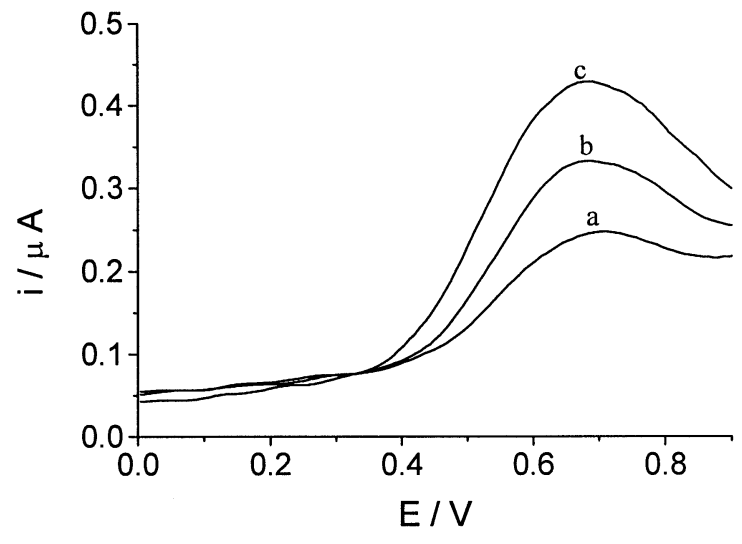

Fig. 2 Typical differential pulse voltammograms of $5 \mathrm{mM} \mathrm{H}_{2} \mathrm{O}_{2}$ (a), addition of $1 \times 10^{-6} \mathrm{M}$ atrazine (b), or addition of $5 \times 10^{-8} \mathrm{M}$ paraquat (c) in a Tris- $\mathrm{HCl}$ buffer solution $\left(\mathrm{pH} \mathrm{7.4)}\right.$ at $30^{\circ} \mathrm{C}$. Pulse amplitude, $50 \mathrm{mV}$; potential scan rate, $100 \mathrm{mV} / \mathrm{s}$; pulse frequency, 4 /s.

reference and platinum wire were dipped into a sample solution. The oxidation current of hydrogen peroxide was measured using a differential pulse voltammetric method over a potential range of $0-0.9 \mathrm{~V}$ at a potential scan rate of $100 \mathrm{mV} / \mathrm{s}$ and a pulse amplitude of $50 \mathrm{mV}$; the current without herbicide was $i_{0}$. The solution was stirred by a magnetic bar for $40 \mathrm{~s}$ after herbicides were added, and the current $(i)$ was then recorded. The enzyme activity inhibition was represented by the value of $\Delta i\left(i-i_{0}\right)$. The presented result was an average of three measurements. After each measurement, the sensor was cleaned with water, and immersed in a stirring Tris- $\mathrm{HCl}$ buffer for $2 \mathrm{~min}$. Typical differential pulse voltammograms are presented in Fig. 2.

\section{Results and Discussion}

Immobilization of thylakoid and activity of thylakoid-bound enzymes

Scanning electron micrographic (SEM) images of thylakoid in PVA-SbQ membrane, which had been stocked at $-20^{\circ} \mathrm{C}$ in a refrigerator for 3 months, are presented in Fig. 3. The figure indicates that the isolated grana were spread uniformly in the PVA-SbQ membrane, and exhibited an integrated exterior. Thylakoid membranes were stacked and the framework was in good order. It was obvious that thylakoid had been successfully embedded in a cross-linking matrix of PVA-SbQ after photopolymerization. This convenient method to immobilize thylakoid seems to be available for the long-time storage of biomaterials.

Several papers have reported on the photosyntheses of chloroplast and thylakoid immobilized in polymers. ${ }^{15,25}$ However, to our knowledge, there has been no paper concerning the enzyme activity on scavenging hydrogen peroxide in crosslinking matrixes. Figure 4 shows the experimental values of the activities $\left(i-i_{0}\right)$ of thylakoid immobilized in a PVA-SbQ crosslinked matrix for different storage times. It was found that the membrane was stable for more than 1 month without any loss of activity at $-20^{\circ} \mathrm{C}$. Then, $89.5 \%$ of activity still remained in the 2nd month, and $50 \%$ in the 6th month. Thus the thylakoid/PVA-SbQ membrane is available for using more than half a year. Compared with the short lifetime in isolated thylakoid, ${ }^{18,21}$ it is possible that the PVA-SbQ network is suitable for thylakoid immobilization, and the enzymes in a good microenvironment keep their activity for a long time. This

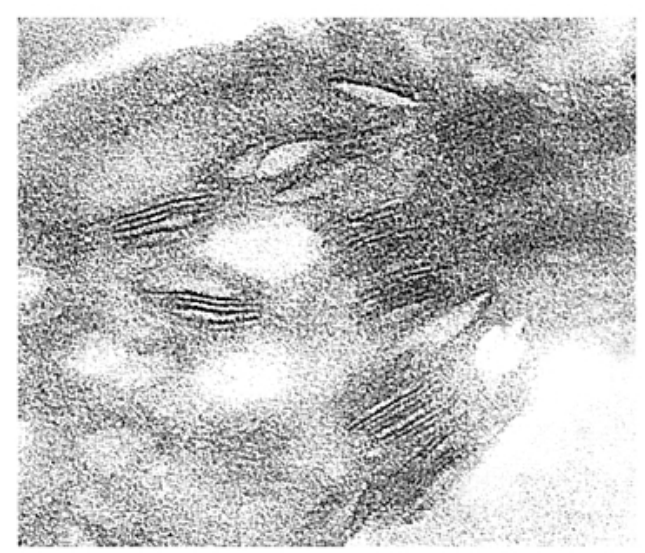

Fig. 3 Scanning electron micrographs of thylakoid immobilized in a PVA-SbQ membrane $(\times 30000)$.

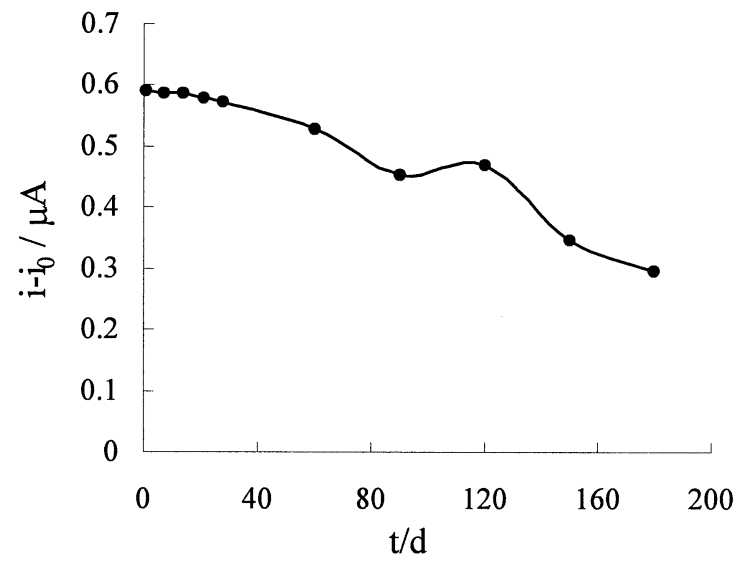

Fig. 4 Activity of thylakoid immobilized in a PVA-SbQ crosslinking matrix. Measurements were carried out in a Tris-HCl buffer solution at pH 7.4 with $8 \mathrm{mM} \mathrm{H}_{2} \mathrm{O}_{2}$ and $4 \times 10^{-6} \mathrm{M}$ atrazine

stability is useful for prospective field measurements and to avoid repeated isolation procedures of thylakoid.

\section{Optimization of detective conditions}

The sensor for detecting herbicides is based on the inhibiting the effect of enzymes in thylakoid on the scavenging of hydrogen peroxide. The degradation efficiency is dynamically relative to the concentration of hydrogen peroxide. However, a high concentration of hydrogen peroxide is poisonous to the enzyme system. In our experiment, hydrogen peroxide is a substrate for the indirect determination of herbicides. The concentration of hydrogen peroxide should be in a range, which is suitable either for an enzymatic reaction or for an electrochemical measurement. Figure 5 presents the effect of the hydrogen peroxide concentration on $\Delta i$. From this figure, the concentration of $8 \mathrm{mM}$ was chosen to obtain a sensitive current that is proportional to the atrazine inhibition effects.

Several weak alkaline buffers simulated to a physiological condition including phosphate, borate and Tris- $\mathrm{HCl}$ solutions were tested; the last buffer was chosen because of a high activity-inhibition was gained.

There are several factors concerning the $\mathrm{pH}$ value of a solution, i.e., the degradation efficiency of enzymes on hydrogen peroxide; the inhibiting reaction of herbicide on an 


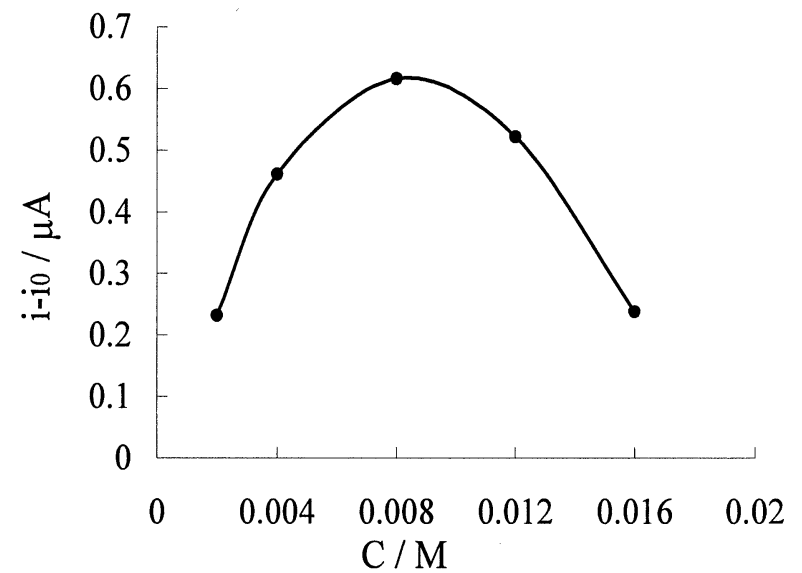

Fig. 5 Effect of the $\mathrm{H}_{2} \mathrm{O}_{2}$ concentration on the thylakoid activity. Other conditions are as in Fig. 4.

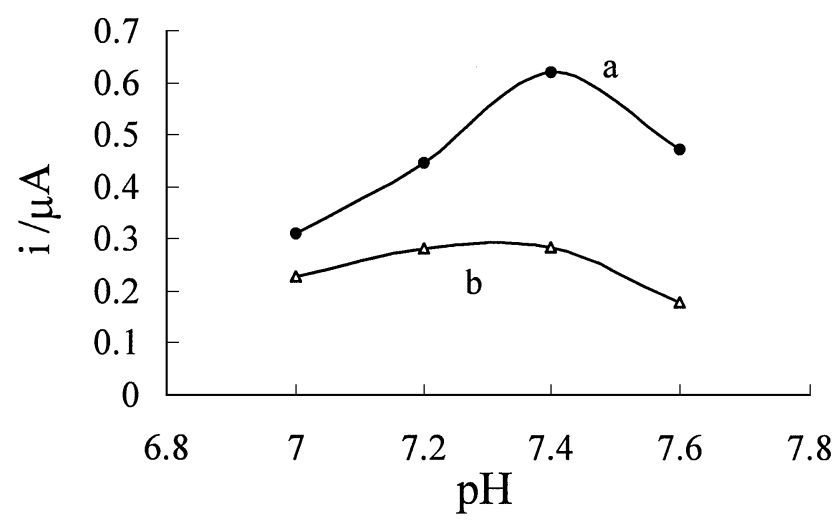

Fig. 6 Effect of the $\mathrm{pH}$ value in a Tris- $\mathrm{HCl}$ buffer solution on the oxidize current of $8 \mathrm{mM} \mathrm{H}_{2} \mathrm{O}_{2}$ (a) and the current difference with 2.5 $\times 10^{-6} \mathrm{M}$ atrazine (b)

enzyme; the stability of hydrogen peroxide and the oxidation of hydrogen peroxide on a platinum electrode surface. The sensor's responses to atrazine were measured in $0.05 \mathrm{M}$ Tris- $\mathrm{HCl}$ buffers with $\mathrm{pH}$ values from 7.0 to 7.6. The result is shown in Fig. 6. It demonstrated that the maximum current was obtained at $\mathrm{pH} 7.4$ (a) for a solution without an inhibitor, while the sensor exhibited the greatest inhibitor activity in a $\mathrm{pH}$ range of $7.2-7.4$ (b) in an atrazine solution. A pH value of 7.4 was selected for further experiments.

The effect of temperature was examined from $10-40^{\circ} \mathrm{C}$, and the results are shown in Fig. 7. The scavenging of hydrogen peroxide was sensitive to temperature. The entrapped thylakoid had an increased inhibitor activity with temperature from 10 to $20^{\circ} \mathrm{C}$, and a maximum between $20-25^{\circ} \mathrm{C}$. The optimum temperature of $25^{\circ} \mathrm{C}$ was chosen for our experiments. A constant temperature was kept by cyclic flowing water.

\section{Repetitive measurement}

A sensor with the same piece of thylakoid-entrapped membrane was used repetitively to measure $2.5 \times 10^{-6} \mathrm{M}$ atrazine in a $8 \mathrm{mM}$ hydrogen peroxide solution. The results showed that the inhibitor activity (expressed as $i / i_{0}$ ) remained at 95\% after $15 \mathrm{~min}$ (10 times of determination). The value of $i / i_{0}$ was $87 \%$ after $30 \mathrm{~min}$, and $35.1 \%$ after 120 min (Fig. 8).

It is obvious that the inhibiting reaction of the thylakoid

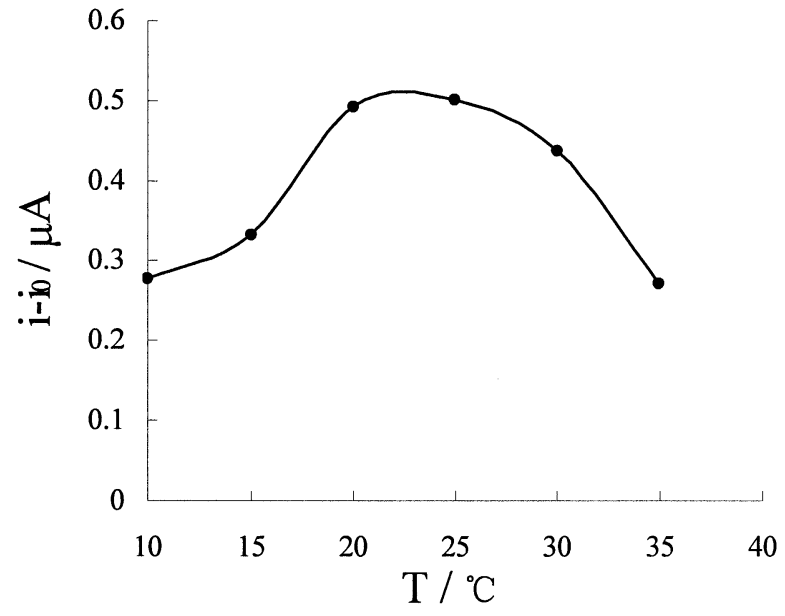

Fig. 7 Effect of the temperature on the determination of $4 \times 10^{-6} \mathrm{M}$ atrazine. Other conditions are as in Fig. 4.

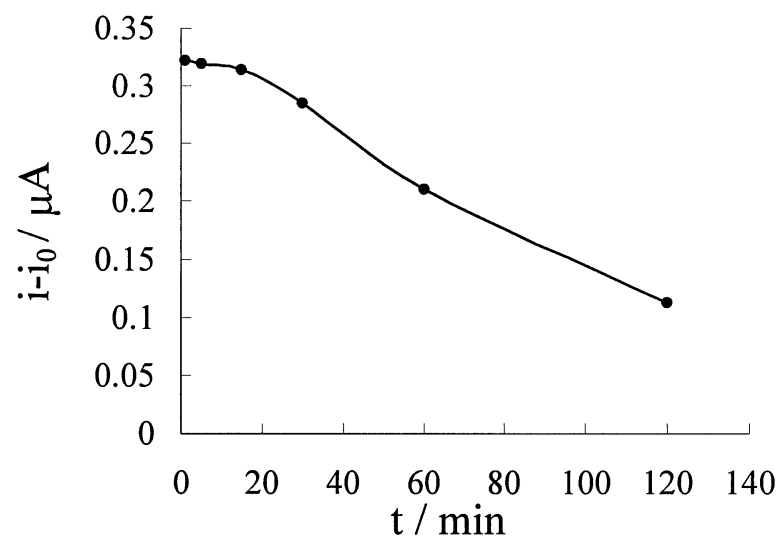

Fig. 8 Repetitive measurement using one piece of thylakoid/PVASbQ membrane with $2.5 \times 10^{-6} \mathrm{M}$ atrazine. Other conditions are as in Fig. 6.

membrane was irreversible. We also found that the membrane became sticky and adhered partly on the electrode surface after a long time of determination. It is recommended to use a new membrane after 20 times of repetitive measurements.

\section{Response time}

The response time of the sensor relies on the reaction rate between the enzyme and the herbicide, and the rate of enzymecatalytic degradation of hydrogen peroxide. Further, it also depends on the diffusion and concentration equilibrium of hydrogen peroxide in the reactive layer near the platinum electrode surface. Experiments involving seven sensors showed that the average of response time was less than $40 \mathrm{~s}$. This time is much shorter than sensors based on PSII inhibiting. ${ }^{12-16}$

\section{Reproducibility}

The reproducibility of the sensor was evaluated by the replicated analysis of $1.0 \times 10^{-6} \mathrm{M}$ atrazine using one sensor, and the atrazine solution was measured three times each day over a period of 7 days. The relative standard derivation (RSD) for the mean values of each day was found to be $5.3 \%$. At the same time, an RSD of $3.7 \%$ was obtained for 11 determinations with one piece of thylakoid membrane. 

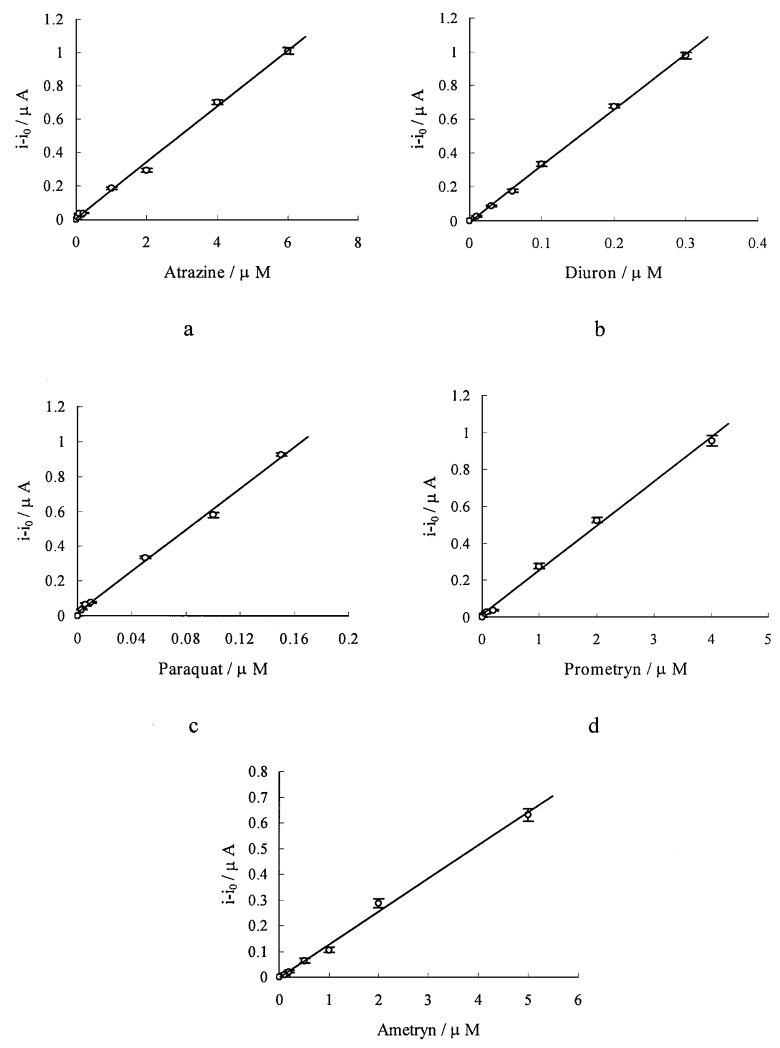

e

Fig. 9 Calibration curves of atrazine (a), diuron (b), paraquat (c), prometryn (d) and ametryn (e). The error bars represent the standard deviation $(n=3)$

\section{Calibration graphs}

Under the optimizing conditions, calibration graphs of several kinds of herbicide, paraquat, diuron, prometryn, atrazine and ametryn are shown in Figs. $9(\mathrm{a}-\mathrm{e})$. There was linear relationship between the inhibition and the herbicide concentrations in the ranges of $3 \times 10^{-9}-1.5 \times 10^{-7} \mathrm{M}$ for paraquat, $1 \times 10^{-8}-3 \times 10^{-7} \mathrm{M}$ for diuron, $4 \times 10^{-8}-4 \times 10^{-6} \mathrm{M}$ for prometryn, $5 \times 10^{-8}-5 \times 10^{-6} \mathrm{M}$ for atrazine and $1 \times 10^{-7}-5$ $\times 10^{-6} \mathrm{M}$ for ametryn, respectively.

The detection limit for the paraquat measurement was $9.8 \times$ $10^{-10} \mathrm{M}$, which was determined according to the expression 3 $\mathrm{s} / \mathrm{K}$. The value approaches the admissible level of $0.1 \mu \mathrm{g} / \mathrm{L}$ (5.4 $\times 10^{-10} \mathrm{M}$ ), recommended by EU for individual herbicides in the environment. The detection limits of other herbicides were also obtained by the same method: $1.8 \times 10^{-9} \mathrm{M}$ for diuron; $1.4 \times$ $10^{-8} \mathrm{M}$ for prometryn; $2.5 \times 10^{-9} \mathrm{M}$ for atrazine and $4.5 \times 10^{-8}$ $\mathrm{M}$ for ametryn, respectively.

\section{Comparison of the enzyme activities of thylakoid immobilized in} different matrix

Three thylakoid immobilized membranes of PVA-SbQ, glutaraldehyde-BSA and alga gel containing the same concentration of chlorophyll were prepared, respectively. The responses of the electrodes based on these membranes to hydrogen peroxide were tested for difference storage times. Table 1 gives the slopes of the calibration curves for hydrogen peroxide determination. It is obvious that PVA-SbQ membrane exhibited higher enzyme activities for different storage times.
Table 1 Remaining activities of thylakoids immobilized in different materials

\begin{tabular}{cccc}
\hline \multirow{2}{*}{$\begin{array}{c}\text { Storage } \\
\text { time/d }\end{array}$} & \multicolumn{3}{c}{ Sensitivities } \\
\cline { 2 - 4 } & PVA-SbQ & Glutaraldehyde-BSA & Alga gel \\
\hline 7 & 0.84 & 0.58 & 0.26 \\
14 & 0.80 & 0.26 & 0.19 \\
21 & 0.78 & 0.19 & 0.15 \\
28 & 0.76 & 0.20 & 0.13 \\
35 & 0.75 & 0.18 & 0.11 \\
\hline
\end{tabular}

Table 2 Analytical results of paraquat in samples

\begin{tabular}{ccccc}
\hline Sample & $\begin{array}{c}\text { Paraquat found/ } \\
\mathrm{nM}(n=5)\end{array}$ & $\begin{array}{c}\text { RSD, } \\
\%\end{array}$ & $\begin{array}{c}\text { Paraquat added/ } \\
\mathrm{nM}\end{array}$ & $\begin{array}{c}\text { Recovery, } \\
\%\end{array}$ \\
\hline Water sample & 0.28 & 4.7 & 0.2 & 91.2 \\
& & & 0.4 & 96.4 \\
Soil sample & 0 & - & 0.2 & 105.8 \\
from field & & & 0.4 & 92.5 \\
\hline
\end{tabular}

\section{Determination of paraquat and atrazine}

In order to determine herbicides with ultra-low concentrations in real samples, a silica gel column was used for accumulation. First, $1000 \mathrm{ml}$ of water sample was collected in a bottle from the field where paraquat had been used. The samples were filtered and $1 \mathrm{ml}$ of 5\% EDTA was added to remove various metal ions. They were then allowed to pass though a silica-gel column at a flow rate of $7 \mathrm{ml} / \mathrm{min}$. The silica-gel column was prepared by packing $6 \mathrm{~g}$ of silica-gel into a $25 \mathrm{ml}$ glass column (9-10 $\mathrm{mm}$ in diameter) with a plug of glass wool placed just above the stopcock. The paraquat was adsorbed by the silica gel, and then eluted by passing $50 \mathrm{ml}$ of saturated ammonium chloride at a flow rate of about $3 \mathrm{ml} / \mathrm{min}$. It was collected in a $50 \mathrm{ml}$ calibrated flask and the volume was made up to the mark with water. Then, $5-7 \mathrm{ml}$ aliquot of this solution was taken for detection using the proposed method.

For soil samples, after $25 \mathrm{~g}$ of soil was collected from the field. The sample was ground in a mill, $1 \mathrm{ml}$ of EDTA and 150 $\mathrm{ml}$ of water were added in the sample, and the suspending solution was then filtered. The filtrate was treated and determined in the same way as above procedure. The results are given in Table 2. Finally, a known amount of paraquat was added to these samples and determined. A recovery was found from $97-104 \%$.

A recovery experiment of atrazine was also carried out using the sensor. Different volumes of atrazine solution were sprayed on the soil samples ( $25 \mathrm{~g}$, no atrazine was been detected). After drying, the samples were ground and $35 \mathrm{ml}$ of methanol and 35 $\mathrm{ml}$ of $0.05 \mathrm{M} \mathrm{CaCl}_{2}$ were added. The mixture was then shaken for $50 \mathrm{~min}$ and filtrated by a vacuum pump. The residues were washed using $50 \mathrm{ml}$ of $50 \%$ methanol. The filtrate were extracted on a $10 \mathrm{ml}$ glass column (5 $\mathrm{mm}$ in diameter) packed with $3 \mathrm{~g}$ of Sep-Pak $\mathrm{C}_{18}$-bonded silica particles, which had been conditioned with $10 \mathrm{ml}$ of methanol and $20 \mathrm{ml}$ of deionized water. Atrazine was then eluted by running thrice $2 \mathrm{ml}$ of methanol. The eluate was evaporated under a gentle stream of nitrogen and the aqueous residue was transferred into a $10 \mathrm{ml}$ flask and was made up to the mark with water; $5-7 \mathrm{ml}$ aliquot of this solution was determined. The determination results are given in Table 3. 
Table 3 Analytical results of atrazine in samples

\begin{tabular}{cccc}
\hline $\begin{array}{c}\text { Atrazine added } \\
(\mu \mathrm{mol} / 25 \mathrm{~g})\end{array}$ & $\begin{array}{c}\text { Found } \\
(\mu \mathrm{mol} / 25 \mathrm{~g})\end{array}$ & RSD, \% & Recovery, \% \\
\hline 1.20 & 1.09 & 7.76 & 90.8 \\
2.00 & 0.937 & 5.40 & 93.7 \\
3.00 & 0.952 & 3.43 & 95.2 \\
\hline
\end{tabular}

\section{Conclusion}

A novel biosensor for monitoring herbicides based on the inhibition of enzyme activity for the degradation of hydrogen peroxide has been proposed. This sensor provides sensitive determination for several kinds of herbicides, including paraquat (dipyridine ramification), diuron (carbamide), prometryn (s-triazine), atrazine (s-triazine) and ametryn (striazine) respectively. This sensitive, rapid-responsible sensor with a disposable membrane is suitable for on-site and real-time analysis, and acts as a first warning device in environmental investigations

Furthermore, other substances, e.g. some heavy metal ions and pesticides, could also perform the similar inhibition to AsADOP. This kind of inhibiting action has been observed in our laboratory. It is possible using this sensor to detect pesticides, heavy metal ions by means of different procedures of sample pretreatment. The detailed studies concerned the performance.

\section{References}

1. C. E. Boyd and L. Massaut, Aquacultural Engin., 1999, 20, 113.

2. J. L. Tadeo, C. Sanchez-Brunete, R. A. Perez, and M. D. Fernandez, J. Chromatogr., A, 2000, 882, 175.

3. R. Castro, E. Moyano, and M. T. Galceran, J. Chromatogr., A, 2000, 869, 441

4. M. Meusel, D. Trau, A. Katerkamp, F. Meier, R. Polzius, and K. Cammann, Sens. Actuators, B, 1998, 51, 249.

5. A. Brecht, A. Klotz, C. Barzen, G. Gauglitz, R. D. Harris, G. R. Quigley, J. S. Wilkinson, P. Sztajnbok, R. Abuknesha, J. Gascon, A. Oubina, and D. Barcelo, Anal. Chim. Acta, 1998, 362, 69.

6. M. Trojanowicz and M. L. Hitchman, Tre. Anal. Chem., 1996, 15,38

7. T. Panasyuk-Delaney, V. M. Mirsky, M. Ulbricht, and O. S. Wolfbeis, Anal. Chim. Acta, 2001, 435, 157.
8. M. F. Yulaev, R. A. Sitdikov, N. M. Dmitrieva, E. V. Yazynina, A. V. Zherdev, and B. B. Dzantiev, Sens. Actuators, B, 2001, 75, 129.

9. R. W. Keay and C. J. McNeil, Biosens. Bioelectron., 1998, 13, 963.

10. J. P. Mastin, C. A. F. Striley, R. E. Biagini, C. J. Hines, R. D. Hull, B. A. MacKenzie, and S. K. Robertson, Anal. Chim. Acta, 1998, 376, 119.

11. C. Nakamura, M. Hasegawa, N. Nakamura, and J. Miyake, Biosens. Bioelectron, 2003, 18, 599.

12. M. Koblizak, J. Masojidek, J. Komenda, T. Kucera, R Pilloton, A. K. Mattor, and M. T. Giardi, Biotechnol. Bioeng., 1998, 60, 664.

13. L. Campanella, F. Cubadda, M. P. Sammartino, and A Saoncella, Water Res., 2001, 35, 69.

14. M. T. Giardi, M. Koblízek, and J. Masojídek, Biosens. Bioelectron., 2001, 16, 1027.

15. E. V. Piletskaya, S. A. Piletsky, T. A. Sergeyeva, A. V. El'skaya, A. A. Sozinov, J. L. Marty, and R. Rouillon, Anal. Chim. Acta, 1999, 391, 1.

16. R. Rouillona, M. Tocabens, and R. Carpentier, Enzyme Microb. Technol., 1999, 25, 230

17. J. P. Li, T. Z. Peng, and X. R. He, Chin. J. Anal. Chem., 2004, 32, 884 .

18. B. Saad, M. Ariffin, and M. I. Saleh, Talanta, 1998, 47, 1231.

19. K. Rekha, M. D. Gouda, M. S. Thakur, and N. G. Karanth, Biosens. Bioelectron., 2000, 15, 499.

20. A. N. Ivanov, G. A. Evtugyn, R. E. Gyurcsányi, K. Tóth, and H. C. Budnikov, Anal. Chim. Acta, 2000, 404, 55.

21. G. Jeanty and J. L. Marty, Biosens. Bioelectron., 1998, 13 , 213.

22. T. T. Bachmann and S. R. D. Chmid, Anal. Chim. Acta, 1999, $401,95$.

23. R. Rouillon, J. J. Mestres, and J. L. Marty, Anal. Chim. Acta, 1995, 311, 437.

24. B. K. Sohn, B. W. Cho, C. S. Kim, and D. H. Kwon, Sens. Actuators, 1997, 41, 7.

25. Y. H. Liu, T. H. Dam, and P. Pantano, Anal. Chim. Acta, 2000, 419, 215.

26. M. Suzuki and H. Akaguma, Sens. Actuators, B, 2000, 64, 136

27. T. Uhlich, M. Ulbricht, and G. Tomaschewski, Enzyme Microb. Technol., 1996, 19, 124

28. H. Zopes, S. Klapheck, and L. Bergmann, Plant Cell Physiol., 1993. 34, 515.

29. H. Y. Nakatan and J. Barber, Biochim. Biophys. Acta, 1977, $461,510$.

30. D. I. Arnon, Plant Physiol., 1949, 24, 1. 